\title{
THE PORTUGUESE INFLUENCE ON AFRIKAANS WITH PARTICULAR REFERENCE TO MILITARY LANGUAGE
}

\author{
Brig (Dr) J.H. Picard*
}

\begin{abstract}
$\mathrm{Na}$ 'n kort historiese uiteensetting van die opkoms van die Portugese seevaarders en hul belangrikheid vir die ontwikkelding van die Afrikaanse vasteland en veral Suid-Afrika, word ander historiese kontakpunte in oorsig geneem: Tussen die Portugese en die VOC in 1725 in Mosambiek; tussen Louis Trichardt en die Portugese Goewerneur in 1838; tussen Albasini en die trekkers in Schoemansdal; tussen die Dorslandtrekkers en die Portugese owerhede in 1875 in Angola; tussen die Zuid-Afrikaanse Spoorwegmaatschappij en die owerhede in Mosambiek in 1890; tussen die boerekrygsgevangenes en die Portugese in Tomar en Abrantes; en die huidige bydrae van Portugese immigrante tot die RSA.
\end{abstract}

Die stryd om koloniale heerskappy tussen die Hollanders en Portugese het 'n invloed gehad op die Nederlandse taal, ook via Maleis, en later op Afrikaans. Portugese invloede op Afrikaans word veral gevind in plekname, boom-, plant-, vrugte-, voedsel-, huishoudelike en geregtename, in die Afrikaanse idioom, in vissoorte, in skeepsterme, in seemansterme en veral in militêre benamings en terme, wat omvattend behandel word.

\section{Historical Setting}

Under the guidance and inspiration of Prince Henry the Navigator, son of king Joao I of Portugal, the Portuguese navigators discovered the Canary Islands, conquered Ceuta (1415), discovered Madeira (1420) and one year after Joao's death in 1433 reached the West African Coast Cape Bojador. The next phases of discovery and colonisation were Cape Verde, the mouth of the Senegal River and Sierra Leone in $1445 / 46$. Next, colonists were sent to Madeira and the Azores. Alphonso V took Tangier in 1471 and in 1482 the fort Sao Jorge da Mina (Elmina) was built to protect the trade in the Gulf of Guinea. In those years the most priceless commodities were ivory, sugar cane, slaves and gold. Contact with the so-called Monomatapa (Zimbabwe) and the legendary Prester John were very strong inducements indeed. Diego Cao discovered the mouth of the Congo river in 1485 and Bartolomeo Dias rounded the Cape of Good Hope to land at Mossel Bay in 1488. The treaty of Tordesillas gave Portugal control over all territories situated less than 370 miles west of Cape Verde. Under the rule of king Manuel I who succeeded Joao II (1481-1495) Vasco da Gama rounded the Cape to discover the sea route to India, thus capitalizing on the work of Dias. The period 1498 to 1580 witnessed the development and fruition of the Portuguese colonial empire. These brief details set the scene for our topic, the influence of the Portuguese on our country and in particular on the Afrikaans Military language. However, the military sphere is never divorced from all other spheres of endeavour and hence we shall deal with more than military terms - we shall in fact touch on the Portuguese influence on the broad spectrum of the Afrikaans language as well. Although I have touched on the Malay/Portuguese influence in a previous paper (1987), Leal (1978) had also already undertaken a study on this aspect and I owe much to his work.

Although Dias was not the only discoverer of importance to South Africa, he is nevertheless the one most closely associated with the Cape, the starting point of South Africa as we know it today. History tells us that before being blown off course around the Cape, Dias had left his supply ship near the coast of Angola, at Baia dos Tigres. As he landed in Mossel Bay on 3 February 1488 he had not even seen the Cape although he and his navigator de Alenquer realised that they must have rounded the Cape. Dias had an easier journey up the East Coast where he rounded Cape Recife (Cabo da Roca) in the third week of February 1488 and anchored between Baia da Roco (Algoa Bay) and ilha da Cruz (St Croix Island) where he planted a wooden cross on the island after having experienced an unsuccessful mutiny on board. On 12 March he anchored off Kwaaihoek, his furthest point east, where he erected his first stone cross (padrao) the rests of which were unearthed by 
Prof Eric Axelson and are kept at Wits University today.

On the journey back he moored at Struisbaai and Cape Agulhas (Cape of needles - the name he gave this Cape). In June 1488 Dias sailed again around the Cape calling it Cabo de Boa Esperanca (Cape of Good Hope). Remains of a padrao said to have been erected there, have never been found. From Table Bay he sailed back up the West Coast and reached today's Luderitz Bay which he called Angra das Voltas, where he erected his last padrao. Returning via Baia dos Tigres, where he found only three crew members still alive on his supply ship, he reached Portugal in December 1488. His achievement was eclipsed by Vasco da Gama in 1497 who was credited with actually having opened the way to India. In 1503 Antonio de Saldanha rounded the Cape and en route there gave his name to the bay of Saldanha, calling it the watering place of Saldanha, and he was the first to climb Table Mountain which he also named. In 1507 Francisco d' Almeida rounded the Cape en route to India to assume the post of first Viceroy of India. D'Almeida, a knight in the Order of Christ and highly regarded in that order, was said to have been involved in the battle of Granada. On the way back from the East in March 1510 D'Almeida was killed at Table Bay.

These four Portuguese, Dias, Da Gama, de Saldanha and D'Almeida all have links with South Africa, links reflected in the places they named; Cape Agulhas, Cape of Good Hope, Table Bay, St Croix Island, Saldanha Bay and others; links which have over the centuries been cemented in strong bonds between South Africa and Portugal.

This was but the beginning. The Dutch overseas empire took over. Van Riebeeck was directed to start a halfway house between the Netherlands and India at the Cape by the Duch East India Company (DEIC), which he did in April 1652. A progressive trading empire such as the DEIC was ever on the look-out for expansion possibilities. More gold and ivory, spices and precious stones were necessary to swell its coffers and interest was especially focussed on Portuguese ports in East Africa for a share in the legendary goldfields of Monomotapa. The Portuguese authorities were ensconced in Fort San Sabastiao on the small island of Moçambique. Efforts by the DEIC to capture the fort between 1603 and 1608 failed, but by 1589 admiral Wybregt van Warwyck had already taken possession of the island Mauritius, which he named after Prince Maurits van Nassauw. The search for Monomotapa was carried on under Governor Simon van der Stel. Under Maurits de Chavonnes an expedition was arranged to Delagoa Bay, the uninhabited bay nearest to the Zimbabwe goldmarket and the present Maputo. Willem van Taak built a fort there, Rio de la Goa (later called Fort Lijdzaamheid). In 1725 Jan van de Capelle, provisional chief of the new colony at Rio de la Goa, sent an expedition under lieutenant Frans de Cuyper with the object of reconnoitring the trade route to the fabulous Gold land of Monomotapa. The expedition, the first Dutchmen ever to set foot in the area now known as the Kruger National Park, had to return due to hostile actions by local tribes. However, the place names and routes recorded by De Cuyper in Beright were valuable long after Fort Lijdzaamheid was evacuated in 1732. In fact, there was considerable information available on the region when the Voortrekkers, and specifically Trichardt, went up north.

In 1838 Louis Trichardt, leader of one of the kommissietreks, reached Moçambique, but malaria took its toll. He, his wife and followers died there, despite the ministrations of the Portuguese Governor and his wife. Later, by way of Portuguese travellers such as Albasini, operating from the Voortrekkerdorp Schoemansdal, and through trading with Moçambique, many bonds were forged with the trekkers. Later contact was made between the Dorsland Trekkers and the Portuguese authorities in Angola after 1875. Although most of the Dorsland Trekkers returned across the Cunene to South Africa and South West Africa, they left their black servants behind, leaving them their family names as well: Van der Merwe, "Lawerskauiing", Dreyer etc. The next point of contact was that between the Transvaal Republic (ZAR) and the Portuguese authorities in Moçambique in the Zuid-Afrikaanse Spoorwegmaatschappij's endeavour to open a railroad to Delagoa Bay, which later operated a regular service. In the last stages of the Anglo-Boer war about 800 Boer prisoners of war were sent to Portugal as internees on the ships Benguella, Zairre and the warship Alfonso de Albuquerque where they were treated more like heroes than as prisoners, and stayed at Abrantes, Tomar, Alcobaça, Caldas de Rainha, Peniche and Oïras. After the revolution in Portugal in the 1970's and the independence of the overseas territories Mocambique and Angola, thousands of Portuguese-speaking refugees settled in South Africa, swelling the population of 


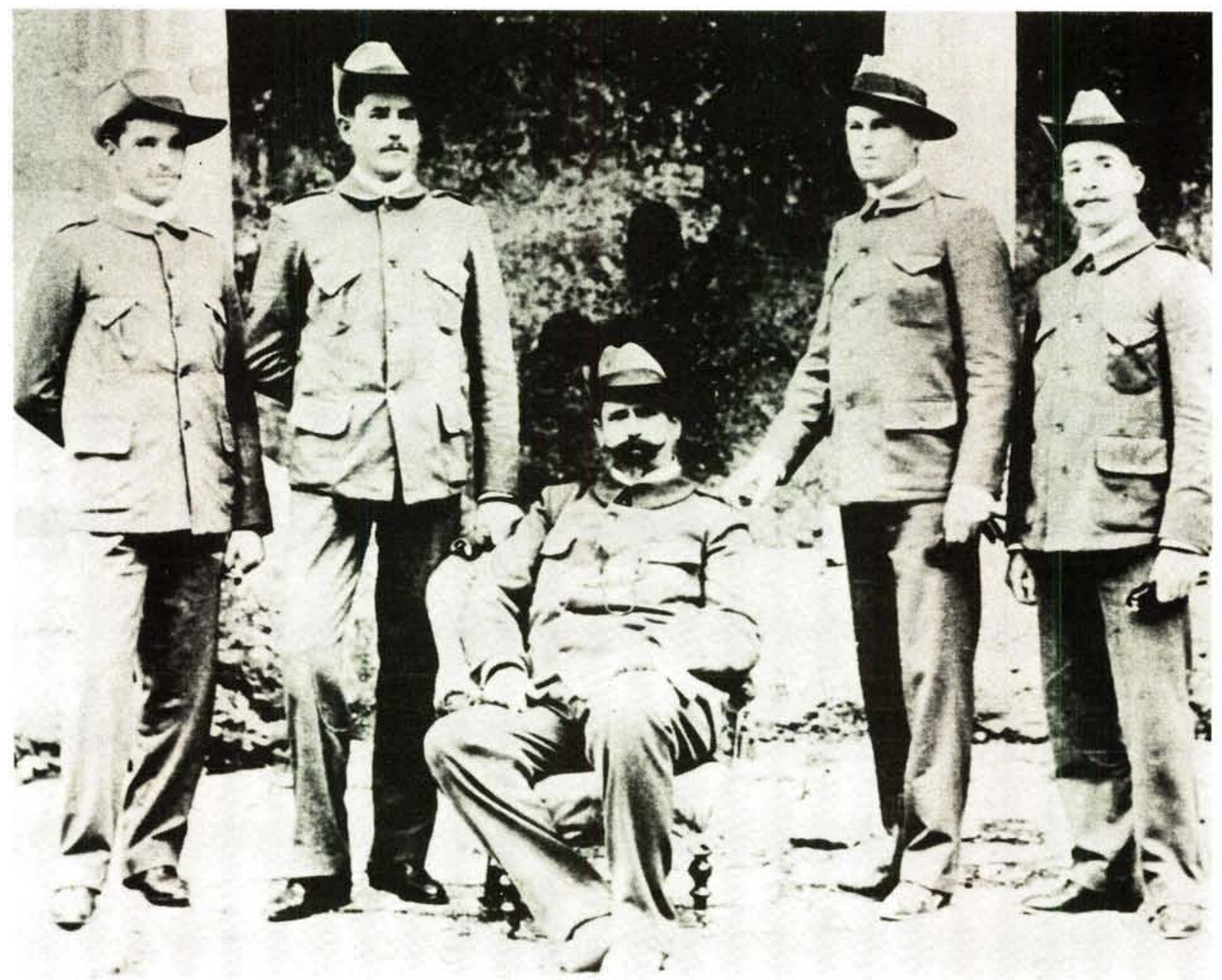

Boer general F.J. Pienaar (seated) photographed with three of his sons and his nephew, F.F. Pienaar (extreme right) who acted as his secretary. F.F. Pienaar later became South Africa's first ambassador to Portugal.

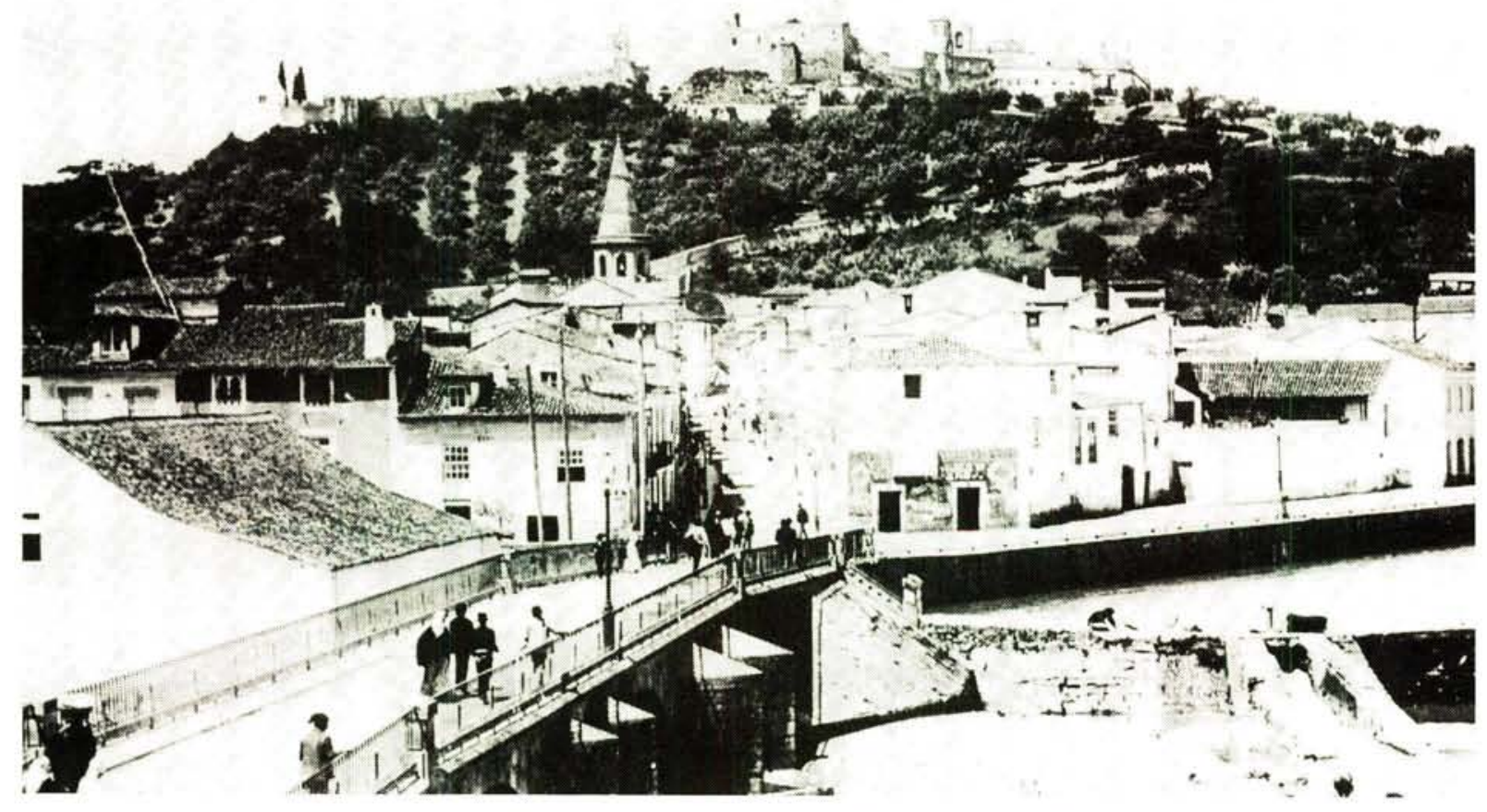

A panoramic view of TOMAR, where some of the Boer prisoners of war were held. 
this country and making a considerable contribution to her economy. Certain battalions in the Military Service are virtually Portuguese-speaking, proving again the influence of the Portuguese language.

\section{Language Contact}

The fight for colonial supremacy between the Dutch and the Portuguese had its influence on the two languages. The Dutch attempted to supplant the Portuguese language in the territories it took over from Portugal, but these efforts were not successful. Portuguese retained its status. Even amongst the slave population in the Cape the language was a mixture of Malay and Portuguese, leading the many linguists searching for the origin of the Afrikaans language to assert that one of the main causes of the change was the influence of the Portuguese-Malay speakers in the Cape (Kloeke, Brill, Valkhoff etc). Examples were cited of aspects such as reduplication boeroelang-oelang and broken Portuguese influences since Portuguese was the lingua franca amongst the slaves.

The truth must lie somewhere between the original South Dutch origin of the settlers, and other influences, together with the natural development of a language spoken by trekkers moving into an unknown region. Historically, however, the continuous contact between the Afrikaans and Portuguese languages has led to the incorporation of many Portuguese lexical elements in Afrikaans. According to Leal 92 lexical elements could be traced (Leal 1978:32). I suspect, however, that this figure may even be higher and one must also, of course, take into consideration the more recent influences since 1975: cuca shop, dama, gripe etc. in addition to the many military words the Portuguese and Dutch Ianguages already had in common. In addition, Kirsipuu (1982) identified many Portuguese plant names which should be added to Leal's list. I think that such a study would be quite a challenge to many post-graduate students.

\section{Portuguese Immigrants}

When Portuguese immigrants arrive in South Africa, they generally speak only a little English apart from their own language. This is probably because English is a more "international" language and many of the visitors to Madeira and Portugal are English or American. But it is interesting to note that after having been in the coun- try a few years and particularly by the second generation, they speak both Afrikaans and English fluently.

According to a South African lady who works in the parish of the Pretoria-West Dutch Reformed Church, Portuguese immigrants start off by sending their children to English schools in South Africa, but after a year or so they are usually placed in Afrikaans schools. It seems (to them) that there is a marked cultural similarity in the Afrikaans and Portuguese population groups, i.e. religious values, extended family ties, discipline, etc.

It is quite natural therefore, that the Portuguese soon feel at home in the Afrikaans community. But initially one does come across English words being "Portuguesised". For instance, instead of speaking of a "lavrador" (a farmer) they speak of "um farmeiro" or a butcher becomes instead of "um talheiro" "um bucheiro" and the insurer, instead of being referred to as "um agente de seguros" becomes "um shorer".

Also as to be expected, quite a few misunderstandings arise. One greengrocer in recounting his initial difficulties in the English language mentioned that a customer asking for a "ripish" paw paw was surprised when the greengrocer fished one out of the dust bin. Another greengrocer asked by an Afrikaans-speaking customer for "maandjie vrugte" brought her wilted fruit, as one of his other customers always bought this for her monkey. The initial effect on the pronunciation of English by the Portuguese is a more nasal one and the final ' $s$ ' in a word is normally pronounced $s h .{ }^{\star 1}$

Among the Portuguese-speaking soldiers of the Army, particularly those people of all racial groups who used to live in Angola and Moçambique the Afrikaans and English languages taught to them or picked up by them, are adapted to their own intonation, pronunciation and vocabulary. These are words which are the same as in Afrikaans for instance "gripe" for flue, papegaai, tarentaal and, interestingly enough, the interjection or confirmatory particle nê: "Dit is mos so, nê?" agrees with (and could even be derived from) the Portuguese "nao é". I cannot prove the latter but it is true that that particle was already used by the Malays in constant contact with the Portuguese seafarers, and could have entered the Afrikaans language via Malay-Portuguese as so many other words have. 


\section{Portuguese Place Names}

I am not going to dwell on the aspect of Portuguese place names since this is the domain of Dr Raper. But it remains true that Portuguese place names in South Africa are of great value both from an historical and from a cultural point of view.

They were, after all, the first names in South Africa bestowed by Europeans and also give us an interesting insight into the customs and beliefs of those early mariners. We will refer to but a few. Angra da Baleia (later on in translation became Walvis Bay), Angra da Conceiçao became Conception Bay, Golfo de Santa Helena became St Helena Bay, Cabo de Boa Esperança, Cape of Good Hope, Cabo das Agulhas, Cape Agulhas, Golfo do Recife: Recife Baai, ilheus da Cruz, St Croix Eiland (Kruiseiland). Terra de Natal became Natal, Ponta de Santa Lucia: St Lucia Baai, while Cape Voltas, a few miles south of Alexander Bay, is one of the first of the Portuguese names which still remain on our charts. Here the bold Diaz turned out to sea after tacking down the wind against strong adverse winds. Angra das Voltas, in the Diaz narrrative, means "Bay of Turns".

St Helena Bay, according to Dr Peringuèy, author of the museum pamphlet on inscriptions and memorials left by early Navigators, was discovered and named by Diaz. However, the historian $\mathrm{Da}$ Castanheda gives the credit to Vasco da Gama. The log of Da Gama's first voyage contains this passage: "On Tuesday, November 7 , we returned to the land, which we found to be low, with a broad bay opening into it. The captain sent Pedro d' Alemquer in a boat to take soundings. Next day we cast anchor in the bay and remained there eight days, cleaning the ships, mending the sails and taking in wood".

Cape Agulhas was the Ponta da St Brendan of Pacheco's narrative. Diaz probably gave it the name of the Irish Saint because he passed it while returning on May 18, 1487, two days after St Brendan's feast day. Some later navigator observed his compass needle pointing due north when he was off Agulhas and so renamed the cape Agulhas - "the needles". Cantino's chart, drawn in 1502, shows Agulhas. According to another theory the Cape derives its name from the thousands of needlesharp rocks found there.

Cape Infanta was probably named by Diaz in honour of one of his captains, Joao do Infante. Then the wide St Sebastian Bay opens out, de- scribed by Perestrello as "large enough to contain a fleet, with a river flowing into it as large as the Tagus". Perestrello dedicated the bay to the Saint.

Mossel Bay retains two Portuguese names Cape St Blaize, where the lighthouse stands, and Cape Vacca (from the original Baia dos Vaqueiros) at the Gouritz River mouth. An eggshaped vase found buried in a bat-guano cave, an old-fashioned anchor, and some pieces of aged greenheart timber found at Mossel Bay may be Portuguese relics. Perestrello wrote: "At this bay, upon the top point of the Cape, I left a wooden cross, and fastened to it a tube enclosed with cork and wax, within which was a document". No trace of these relics has ever been discovered.

When the first Portuguese sailed into Algoa Bay they saw a resemblance between the western entrance (which they called cabo de Recife, "reef of rocks") and Cape Roca, the most western headland of Europe. So they called the bay Baia de Roca, and later Algoa Bay, to describe a lagoon or marsh they found there.

\section{Portuguese Influences in Afrikaans}

Because the Malay influence is so strongly ensconced particularly in the Afrikaans idiom and traditions from the very earliest days in the Cape, some Portuguese lexical elements have always been part of Afrikaans. For we must remember that the Portuguese influence on Malay was profound and, in turn, the Dutch seafarers and the early Afrikaans developed by them and the Cape Malay showed this influence as well. The first Malays arrived at the Cape about 1667, according to Theal. In 1725, 1737 and 1749 further groups of political deportees arrived at the Cape. One of these was Sheik Jussuf, a priest, prince and warrior from Celebes where he had led the resistance against Dutch colonial rule. $\mathrm{He}$ and his followers were exiled to the Cape and his grave (kramat) is in Foure. Another Moslem, this time from Turkey, was Abu Bakar, a Moslem religious expert sent to the Cape to help resolve the religious conflict raging in Cape Malay circles. He started a school where Afrikaans was used as the medium of education for the first time, long before the First Afrikaans language movement. In 1987 I counted more than 170 Malay words in the Afrikaans language, many of them military. I must admit, however, that quite a large number of these words are Portuguese-Malay and some even of pure Portu- 


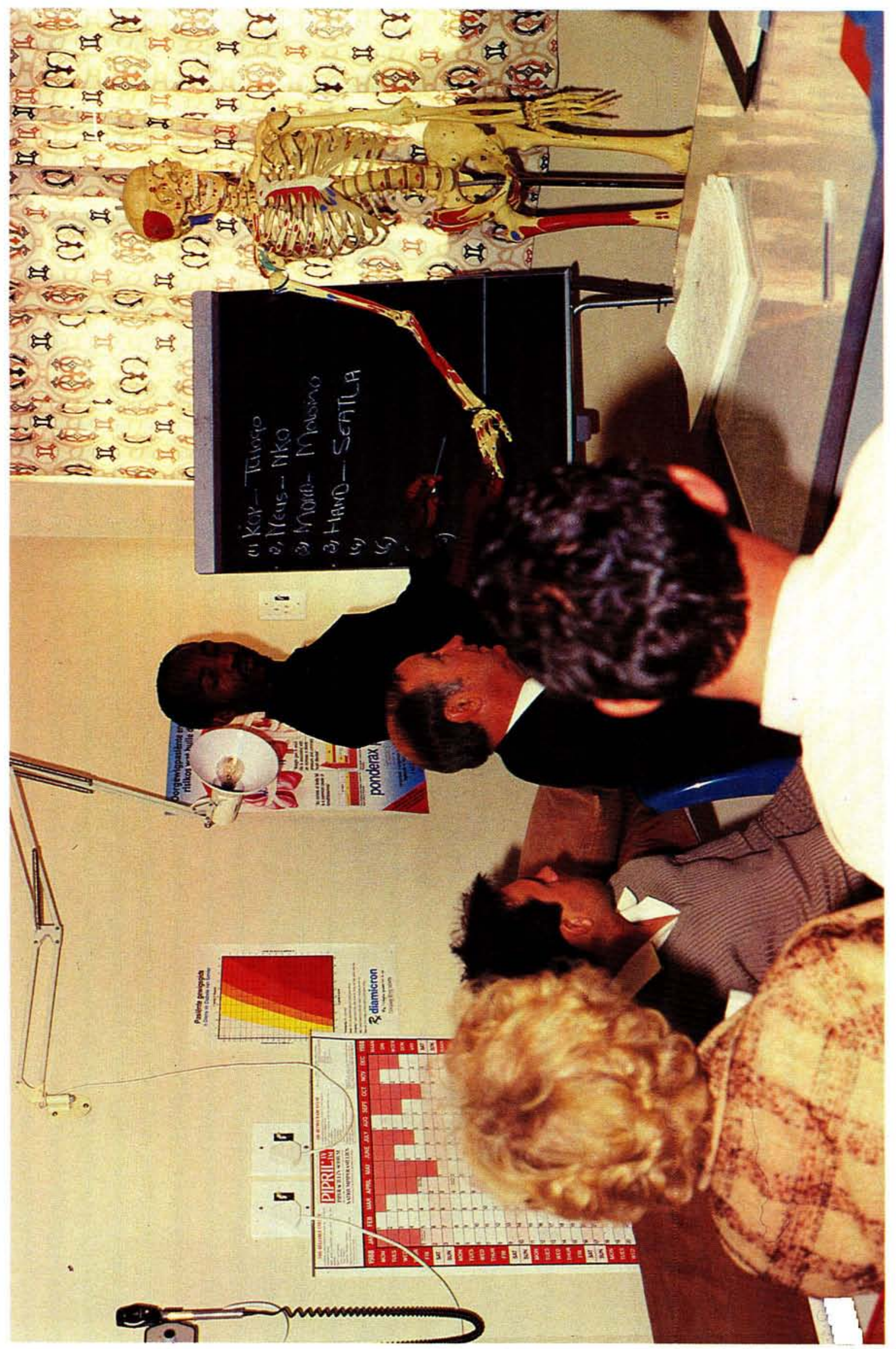




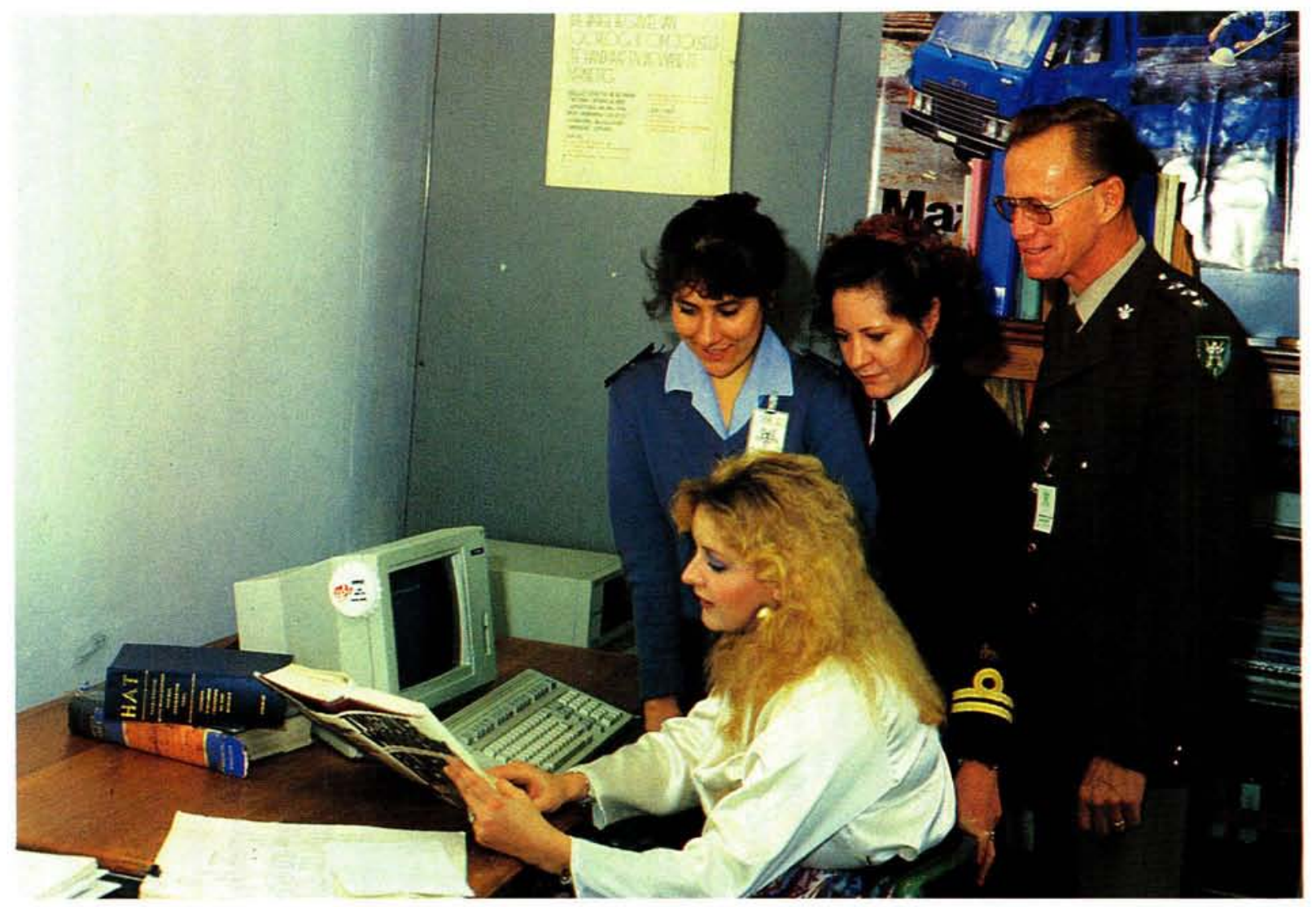

Language practitioners of the Official Languages Section gather around a colleague who is editing a document on a word processor.

(Photograph: Sapper Dirk v.d. Berg)
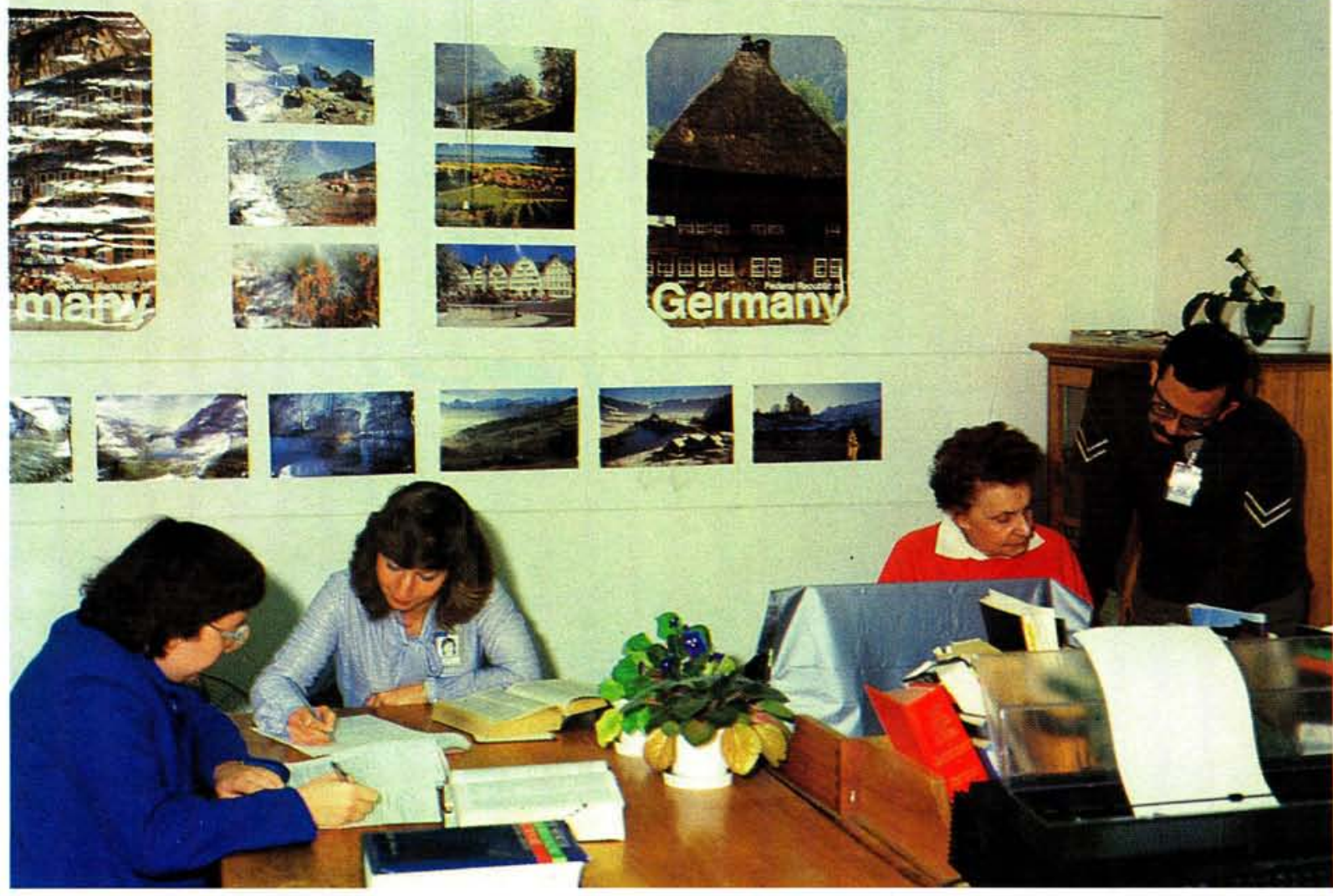

At the Foreign Languages Section translation and editing is done in, inter alia, French, Italian, Spanish, Portuguese, German and Russian.

(Photograph: Sapper Dirk v.d. Berg) 
guese origin. For instance, aia, like ama denoting a children's maid, originated from aia da rainha (woman of the Court) and ama from the Portuguese ama-seica. Albekoor(d) a type of fish originated from the Portuguese albecora; albino, a person without colour pigmentation from the Portuguese albino; ananas (pineapple) from the Portuguese ananazeiro and angostura from the same name of the herb in Portuguese.

In the fields of trees, flowers, fruit, foodstuffs, household effects and dishes, many Portuguese words have crept into the Afrikaans language: kanna, a type of flower from the Portuguese alcana, alkatief from the Portuguese alcatif refers to a type of carpet already recorded in the Beright of Lt Francois de Cuyper, in 1725. Flowers and plants such as altea (Portuguese althea), arraroot (from the Portuguese araruto), bamboes from the Portuguese bambu (recorded in 1563) and the Malay bamboe; betel from the Portuguese betel/betle for that leaf, boeqoe from the Portuguese buchu and Malay boegoe for the herb, brinjal (eggfruit: Portuguese beringela/ bringel, buksboom from the Portuguese buxu tree, dalia from he Portuguese Dahlia for the flower, belombra, a tree from the Portuguese bella-sombra (beautiful shadow which the tree gives); also trees: jakaranda from Brasil, jakka originating from the Portuguese name jacca; kiepersol tree from the Portuguese quita-sol, lietsjie, a fruit, from the Portuguese lichi; koejawel, a fruit; from the Portuguese guayaba; jamboes from the Portuguese jambeiro and the Malay djamboe. Then there are fish types: daeraad from the Portuguese Dorado; barrakoeda from the Brasilian Portuguese name for the fish. Several dishes are also in evidence: bredie, a stew from the Portuguese bredo, atjar, a pickle from Mal-Port origin achar but originally Indian. Fisant, (pheasant) was also known in the Malay version faisin/feijao; we must also not forget a specifically South African type of orchid, the Disa named after Dias, and, of course, tarrentale (wild fowls) named after terra Natal where they were found in their thousands, while the asalea (English azalea) is also of Portuguese origin.

The exclamation of irritation in Afrikaans "arrie nee!" had its origin in the Portuguese arré, whilst assegaai (Portuguese azagaia as recorded in the 15th century) is already of long standing in Afrikaans. The fish type anchova in Portuguese, originally taken over in Afrikaans as assoois, later became ansjovis, indicating how the Portuguese-Malay lexical treasures had already become part and parcel of Afrikaans early tradition many years ago. The same applies to baljaar (play, dance) which derives from the Portuguese bailar/balher (17th century). Interesting is the Afrikaans basjan (bastiaan) for the slave punisher in the old Cape from the Portuguese bastonada (a beating on board ships). The exclamation "Basta!" was taken into Afrikaans from Portuguese unchanged, while the military bastion originated in the Portuguese bastiao. Many other military terms in Afrikaans are shared with Portuguese, either because of the original Latin word for the concept or due to the Malay-Portuguese influence, or indirectly via the Dutch seaman's language. Examples are brigade (Portuguese brigada), desserteer (Portuguese dessertar), detail (Portuguese detalha), ekwipasie (Portuguese equipagen), bajonet (Portuguese baioneta), bandelier (Portuguese bandoleira), battery (Portuguese bataria), bivakkeer (Portuguese bivacar) artillerie (Portuguese artilharia), flank (Portuguese flanco), flottielje (Portuguese flotilha), galjoen (Portuguese galeao) type of warship, guerrilla: irregular fighter (Portuguese guerilha), kalfater. recondition a ship (Portuguese calafatar), kamoefleer (camouflage, Portuguese camuflar), karet (baggage wagon behind car, Portuguese careta), kasarm/kasarring (many, a host of things), from Portuguese caserna: accommodation for other ranks. In Afrikaans the word kaserne is also used in the same sense as the Portuguese and later the Johannesburg Railways Goods Shed, because of its proximity to the barracks, was called kaserne. Fortifikasie was also possibly derived from the Portuguese fortificacao although the English fortification was not unknown. Insurgent and missiel are both recent introductions to the Afrikaans military language respectively from the Portuguese insurgente, referring to an irregular fighter infiltrating into a host country and missil, guided missile/ projectile used in combat. Amongst the Boer forces the expression kasaterwater or kasaat in reference to weak or insipid tea or coffie was well known; it derives from the Portuguese cansada $=$ tired and chasada $=$ weak.

Other military words are kardoes (from Portuguese cartucho: cartridge, container, box); kakie from the Portuguese caque originally probably derived from the Hindu Khakkhi for the field colour of the British uniforms; karabyn (short rifle from the Portuguese carabino), karveel (type of sailing ship used by Diaz from the Portuguese caravela); kepie (headdress from the Portuguese quepi) kavallerie (horse-mounted troops from the Portuguese cavalaria); kolonel, kommandant, kommodoor found respectively in Por- 
tuguese ranks coronel, commandante and commodore. The word laksman (executioner) has an interesting origin: the Portuguese word lacxamana (recorded in 1636) was used by the Malays as laksemana for a chief judge or admiral, the shift in meaning probably occurring because an admiral of the fleet has the power of life and death over those under his command. Laskaar, from the Portuguese lasquarini/lascar referred to Oriëntal sailors; paaiboelie a threatening person from the Portuguese paai ( $p a i=$ vader) plus Malay boele (white man). Palawer negotiate, originates from the Portuguese palavra (word) and Malay pelawi. Paramilitêr is a very recent introduction. Others are patrollie (Portuguese patrulha), pirotegniek (Portuguese pirotecnico), piloot (Portuguese piloto), poncho (Portuguese name for apparel covering head and top part of body, poncho), rekruut (Portuguese recruta [raw soldier]), roete (Portuguese rota $=$ route), rondawel - round building (Portuguese rondavallo = wheel), sappeur (Portuguese sapador engineering corps soldier), soldaat (soldier) from Malay soldadoe derived from the Portuguese soldado, sinjaal derived from the Portuguese sinal (signal), soldy (from the Portuguese soldo = pay), taktiek (tactics) (from the Portuguese tactico), bark (small craft from the Portuguese barco already in 16th century), tenk (reservoir) from the Portuguese tanque, torpedo also from the Portuguese (but other languages also borrowed this word for a water missile); tronk (prison) from the Portuguese tronco, referring to the tree trunk to which prisoners were chained), and vise-admiraal from the Portuguese vice-almirante (almirante having been borrowed by the Portuguese seamen from their Arabic adversaries). Even kapelaan, religious minister for the military, is probably derived via the Dutch seaman's language from the Portuguese capalania.

I am not going to discuss all the terms, words, names and expressions found. You will be given a list containing about 580 . Some of the more interesting folk-items could, however, be high-lighted. The Afrikaans conjunction almiskie/almaskie originates from the Portuguese por mais que; petalje (big to-do) probably originated from the Portuguese batalha. The Afrikaans bokkapater, a castrated goat, originates from the Portuguese capado; kakkerlak from the Portuguese carcalacca; and the expression kaduks (broken, bust) comes from the Portuguese cad$u c o$, while Jalap/Janlap refers back to the Spanish/Portuguese (purga de) Jalapa, a purgative. The expression: "Ek is die josie in" (I am very angry) originally referred to the devil, a magician or astrologist, Portuguese: jousi. Kebaai/kabaai refers to the Malay kabaja from the Portuguese cabaia, a house coat.

The expression "sy kierinkies/kierang gaan braai" (his dishonesty/trickery will come out) is from the Malay kierang/tjoerang which was also known among the Portuguese seamen as a Malay game, ploy or deception. Similarly, the Afrikaans malinger to pretend sickness as excuse for not working, deriving from the Malay melinga, was also known amongst Portuguese seamen. The military word martello toring from Portuguese martelho (to hammer) is still retained in respect of these historical structures. Pikanien (small black boy, from the Portuguese piqueno, and ramkie (musical instrument from the Portuguese rabequinha derived from rabeca (violin) plus piqueno (small) are frequently used in Afrikaans. The troepie-expression poer-poer in "Die majoor poer-poer nou al 3 weke lank en gee nie sy beslissing nie" derives from the Malay poerapoera (poera $=$ do nothing) and was doubled in the Malay reduplication structure which is so well-known in Afrikaans too: see mooi-moois. It could have a Portuguese origin in poeirra (dust/ nothing).

Among the Cape Malay population there are many interesting historical traditions: "met snaar en stramboel" refers to the custom of going to a party on foot accompanied by stringed instruments (see today's custom of Cape Malay "Klopse" at New Year's Eve). The Portuguese tam$b$ (o)era may well be the original stramboel. There are many more interesting Afrikaans deviations from the Portuguese: tamaai (big) derives from the Portuguese tamanho and the Malay soembreloe is clearly derived from the Portuguese sombreiro (hat) which led to the Afrikaans sambreel (umbrella). Kris (dagger) is a word originally taken from the Malay keris, harking back to the Portuguese cris.

The word boer was already known to the Portuguese in Moçambique during the kommissietreks of Trichardt in 1838. The Boer war also introduced the terms redoute (fortification; Portuguese reduto) and remonte (change of horses Portuguese remonte). But there is evidence to suggest that these terms derive not from the Portuguese but from the French terminology of Frenchmen in the Boer ranks such as combat general de Villiebois-Mareuil.

Recent introductions are cuca winkel, general dealer shop so called in Angola, cabaz do Natal 
(Christmas present) since Natal was discovered over Christmas.

All these words and expressions reflect aspects surrounding the daily life of Afrikaans-speaking soldiers and ordinary people or civilians from the time of the Dutch East India Company through the Boer Wars right up to today's battalions. As long as the Portuguese-speaking people have been with us, so long has their language been part of Afrikaans, both in ordinary everyday life and in time of war. This influence is not decreasing and still has relevance today in our country with its more than one million Portuguese-speaking citizens.

*Brig (Dr) J.H. Picard, SM is Director of the SADF Language Service.

\section{Bibliography}

1.1 Boshoff, S.P.E. \& Nienaber, G.S. 1967. Afrikaanse Etimologieë Pretoria: SA Akademie vir Wetenskap en Kuns.

1.2 Bulpin, T.V. 1983. Lost Trails of the Transvaal. Cape Town.

1.3 Das Neves, D.F. 1987. Hunting Expedition to Transvaal. Pretoria: Government Printer.

1.4 De Kock, W.J. 1951. Portugese Ontdekkers om die Kaap. Cape Town; Tafelberg.

1.5 De Vaal, J.B. 1946. "Casimiro Simoes" in die Volkstem. (12.1946).

1.6 De Vaal, J.B. 1953. "Die rol van Joao Albasini in die geskiedenis van Transvaal" in: Argiefjaarboek vir Suid-Afrikaanse Geskiedenis 16(1), 1953. Pretoria: State Archives.
1.7 Green, Lawrence G. 1981. Almost Forgotten, Never Told. Cape Town: Howard Timmins.

1.8 Hofmeyer, S. 1890. Twintig Jaren in Zoutpansberg. Cape Town.

1.9 Hesseling, D.C. 1899. Het Afrikaans. Leiden: Brill.

1.10 Krüger, D.W. 1938. "Die weg na die see of die ooskus in die boerebeleid voor 1877 met spesiale verwysing na die verhouding tot die Portugese" in: Argiefjaarboek vir SA Geskiedenis Jaargang 1 no 1 Kaapstad: Staatsdrukker.

1.11 Krüger, B.W. 1955. "Die weg na die see" in: Argiefjaarboek vir SuidAfrikaanse Geskiedenis (2), 1955. Pretoria: State Archives.

1.12 Kirsipuu, A. 1982. "Names of Useful plants in 5 languages" in: The Language Practitioner 4/1982. Pretoria: SAIVERT.

1.13 Leal, L. 1978. Die Portugese Leksikale Elemente in Afrikaans in Wetenskaplike Bydraes van die PU vir CHO Reeks A. Geesteswetenskappe nr 28.

1.14 Lombard, J.A. 1977. Die Geskiedenis van Sendingwerk deur die Nederduitse Gereformeerde Kerk onder die Buysstam in Noord-Transvaal. Ongepubl. - MA-verhandeling. Stellenbosch: Univ. van Stellenbosch.

1.15 MacQueen, J. 1862. "Journey from Inhambane to Zoutpansberg by Joaquim de Santa Rita Montanha" in: Journal of the Royal Geographical Society (31.1862).

1.16 Paravicini di Capelli, W.B.E. 1965. Reize in de Binnen-Landen van Zuid-Africa. Geredigeer deur de Kock, W.J. Kaapstad: Van Riebeeckgenootskap 46.

1.17 Punt, W.H.J. 1975. Die eerste Europeane in die Nasionale Krugerwildtuin. 1725. Pretoria: National Parks Board of Trustees.

1.18 Punt, W.H.J. 1953. Louis Trichardt se laaste skof. Pretoria.

1.19 Oliver Ransford. 1974. The Great Trek. London: Cox \& Wayman.

1.20 Raper, P.E. 1972. Streekname in SA en Suid-wes. Pretoria: RGN.

1.21 Ed Sabieno, J.C.B., Hafter, P \& Pretorius, J.S. 1975. Portugees-Afrikaanse Woordeboek. Pretoria: UNISA.

1.22 J du P. Scholtz: 1981. Taalhistoriese Opstelle. Cape Town.

1.23 Thiel, G. Mac. 1964 The Portuguese in South Africa. Cape Town.

1.24 Trigardt, L. Ed.T.H. Ie Roux. 1966. Die dagboek van Louis Trichardt. Pretoria.

1.25 Van Asten, F.G. 1955. Die Geskiedenis van Pietersburg en omgewing 1883-1899. Ongepubl. MA-verhandeling UNISA. Pretoria: UNISA.

1.26 Woordeboek van die Afrikaanse Taal. 1984. Deel i, ii, iii, iv, v, vi, vii. Pretoria: Staatsdrukker.

*1 Information from Mrs C.A. von Reiche, 1988. 